\title{
Analiza wybranych czynników mających wpływ na postępowanie rodziców dzieci do 5 roku życia w przypadku wystąpienia gorączki
}

\section{Analysis of chosen factors affecting proceedings of parents of five years old children in case of fever}

\section{DOROTA KOCHMAN1, JOLANTA JAGIEŁA²}

1 Państwowa Uczelnia Zawodowa we Włocławku, Instytut Nauk o Zdrowiu

2 Wojewódzki Szpital Specjalistyczny we Włocławku

DOI: http://dx.doi.org/10.21784/lwP.2020.004

ISSN: 2451-1846

\section{Streszczenie:}

Wstęp. Pojawienie się gorączki u dziecka jest w ocenie rodziców bardzo niepokojącym stanem klinicznym. Występuje on dość powszechnie w populacji pediatrycznej a wiedza dotycząca postępowania przeciwgorączkowego jest ciągle popularyzowana wśród rodziców przez personel medyczny.

Cel. Celem niniejszej pracy jest zwrócenie uwagi na istniejący niewątpliwie problem braku podejmowania odważnych decyzji przez rodziców w stosunku do własnego, chorego dziecka.

Materiał i metody. W niniejszej pracy zastosowano metodę sondażu diagnostycznego przy zastosowaniu techniki ankietowania. Jako narzędzie badawcze do przeprowadzenia badań ankietowych służyła ankieta własnej konstrukcji. W części badania wykorzystano sumaryczną skalę oceny wiedzy rodziców według własnej konstrukcji. Ankietowaną grupę stanowiło 105 osób, rodzice dzieci do 5 roku życia, które były hospitalizowane 
w Oddziałach Dziecięcych z powodu gorączki lub diagnozowane $\mathrm{z}$ tego powodu.

Wyniki. Uzyskane wyniki badań własnych potwierdzają modyfikujący wpływ czynników demograficznych na postępowanie przeciwgorączkowe rodziców dzieci do 5 roku życia. Rodzice posiadają niewystarczającą wiedzę na temat gorączki, interpretacji jej parametrów i sposobów jej obniżenia. Jednocześnie posiadają wiedzę na temat zagrożeń wynikających z niebezpieczeństwa wysokiej gorączki. Ponad 50\% rodziców czerpie wiedzę na analizowany temat $\mathrm{z}$ innych źródeł jakimi są rodzina, znajomi, fora internetowe i nieprofesjonalne media. Fachowy personel medyczny jest źródłem wiedzy w 48,57\% wszystkich ankietowanych. Rodzice i opiekunowie doceniają informacje na temat gorączki przekazywane przez lekarzy i pielęgniarki. Wysoko oceniają poziom i jakość tej wiedzy.

Wnioski. Rola pielęgniarki w edukacji rodziców o gorączce i postępowaniu w przypadku jej pojawienia się jest znacząca. Pielęgniarki są źródłem informacji, ale w różnym stopniu wg rodziców przekazują niezbędną wiedzę. Personel medyczny jest współodpowiedzialny za pogłębianie wiedzy rodziców.

Słowa kluczowe: dziecko, gorączka, rodzice, wiedza, drgawki gorączkowe, postępowanie

\section{Summary:}

Introduction. Children's fever occurring is in parents' opinion a very worrying clinical state. Its appearance is quite common in paediatric population and the knowledge about dealing with the anti-fever issues is still popularised among parents by medical staff.

Aim. The thesis aims to pay attention to the present problem of not taking brave decisions by parents when it concerns their sick child.

Material and methods. In this thesis, a way of diagnostics survey with a technique of polling was applied. A self-made questionnaire was used as the research tool. In the part related to the research, the aggregate scale of parents' knowledge evaluation according to the very own structure. The group consisted of 105 people, the parents of children up to five years old. 
Results. The results confirm the influence of demographic factors on the treatments by the parents when it comes to their children up to five years old. The parents do not have enough knowledge about fever, understanding its parameters and ways of reducing it. At once, they do have knowledge about the risks arising from the hazard of a high fever. More than $50 \%$ of parents get information about the subject from numerous sources such as family, friends, the Internet and unprofessional media. Professional medical staff is the source of knowledge for $48,57 \%$ of people. The parents and caretakers recognise information about fever forwarded by doctors and nurses. They rate the level and the quality of that knowledge very high.

Conclusion. The role of a nurse in parents' education about fever and dealing with it when it appears is significant. Nurses are the source of information, but they forward their knowledge in different degrees, according to parents. Medical staff is co-responsible for deepening parents' knowledge.

Keywords: child, fever, parents, knowledge, febrile convulsions, proceedings

\section{Wstęp}

Gorączka u dziecka jest stanem klinicznym, którego przyczyny zmieniają się w zależności od okresu życia dziecka. U najmłodszych dzieci dominują czynniki infekcyjne układu oddechowego, pokarmowego, dróg moczowych i ośrodkowego układu nerwowego. Dzieci starsze gorączkują najczęściej z przyczyn tzw. nieinfekcyjnych, do których należą choroby immunologiczny, nowotwory, nieswoiste zapalenia jelit czy choroby tkanki łącznej.

Wystąpienie gorączki $\mathrm{u}$ małego dziecka jest jednym z najczęściej występujących problemów zdrowotnych $\mathrm{z}$ jakimi spotykają się rodzice w codziennej opiece nad dzieckiem. Szczególnie niebezpieczna jest ona $\mathrm{u}$ małych dzieci do 5 roku życia, które z powodu charakterystycznej dla tego wieku niedojrzałości układu nerwowego, są najbardziej narażone na pojawienie się drgawek gorączkowych przy wysokiej i nieprawidłowo obniżanej gorączce. 
Drgawki gorączkowe mogą też być zagrożeniem dla zdrowia i życia małego dziecka, szczególnie z obniżoną odpornością i przebywających w dużych skupiskach dzieci, którymi są np. żłobki i przedszkola. Są one bardzo częstym zaburzeniem, które obserwuje się $\mathrm{w}$ populacji pediatrycznej.

Pojawienie się gorączki u dziecka jest najczęściej zwiastunem rozwijającej się infekcji, głównie $\mathrm{w}$ jej początkowym okresie. Wywołuje u rodziców i opiekunów znaczny niepokój, który przekłada się na ich zbyt pochopne poszukiwanie porady i konsultacji lekarskiej. Bardzo istotne jest, aby rodzice potrafili prawidłowo interpretować parametry gorączki, dokonali odpowiedniego doboru miejsca pomiaru i rodzaju termometru.

\section{Cel}

Celem niniejszej pracy jest przeanalizowanie czynników, które wpływają modyfikująco na sposób postępowania rodziców dzieci do 5 roku życia w przypadku wystąpienia gorączki oraz ocena ich wiedzy na ten temat.

\section{Materiał i metody}

Badania zostały przeprowadzone wśród grupy rodziców dzieci do 5 roku życia, którą tworzyło 105 osób. W większość badanych stanowiły dzieci w wieku 1 - 5 lat (71,43\% - 75 osób) w porównaniu do niemowląt (28,57\% - 30 osób). Chłopcy stanowili 50,48\% - 53 dzieci w porównaniu do dziewczynek 49,52\% - 52 dzieci.

Większość ankietowanych rodziców stanowiły matki dzieci - 89,52\% tj. 94 osoby to kobiety, a ojcowie to $10,48 \%$ badanych tj. 10 mężczyzn. Najliczniejsza grupa rodziców była w przedziale 31 - 40 lat $(57,16 \%$ 60 osób). Rodzice w wieku 21 - 30 lat stanowili 22,86\% tj. 24 osoby. Rodziców powyżej 40 lat było 20 osób co stanowi 19,05\%. Jeden rodzic miał poniżej 20 lat. Największą grupę stanowili rodzice 
ze średnim wykształceniem $\quad-\quad 52,38 \% \quad$ (55 osób), następnie w kolejności

osoby

z wyższym wykształceniem $-24,76 \%$ tj. 26 rodziców. 22 osoby miały wykształcenie zawodowe - 20,95\%, tylko 2 osoby oceniły swoje wykształcenie na podstawowe. Największa liczba rodziców - 87 osób, oceniła swoją sytuację materialną jako dobrą (82,86\% ), a 12 osób jako bardzo dobrą (11,43\%). Tylko 6 osób uważa, że ich sytuacja materialna jest przeciętna $(5,71 \%)$. Nikt nie ocenił jej jako złą. Najwięcej rodzin ankietowanych dzieci mieszka waglomeracji miejskiej $68,57 \%$, a w aglomeracji wiejskiej - 33 rodziny, co stanowi 31,43\% badanych. Najwięcej ankietowanych rodzin - 51, posiada dwoje dzieci $(48,57 \%)$, rodzin jedynaków jest $29-27,62 \%$, a 22 rodziny posiadają troje dzieci $(20,95 \%)$. Troje rodziców posiada więcej niż troje dzieci tj. $2,86 \%$.

W niniejszej pracy zastosowano metodę sondażu diagnostycznego przy zastosowaniu techniki ankietowania. Jako narzędzie badawcze do przeprowadzenia badań ankietowych służyła ankieta własnej konstrukcji. W części badania wykorzystano sumaryczną skalę oceny wiedzy rodziców według własnej konstrukcji. Metody statystyczne - Zmienne jakościowe scharakteryzowano poprzez rozkłady częstości. Założenie o normalności rozkładu sprawdzano testem Shapiro-Wilka, a jednorodność wariancji badano testem Levene’a. Ponieważ zostały spełnione założenia dotyczące wykorzystania metod parametrycznych hipotezy statystyczne weryfikowano testem tStudenta dla zmiennych niezależnych oraz jednoczynnikową analizą wariancji (wraz $\mathrm{z}$ testem post-hoc RiRTukeya). Za istotne statystycznie uznawano wyniki, gdy wartość wyliczonego prawdopodobieństwa testowego spełniała nierówność $\mathrm{p}<0,05$. 


\section{Wyniki badań własnych}

W największej grupie dzieci gorączka trwała więcej niż 2 doby (43,81\% - 46 osób), dzieci gorączkujące dłużej niż dobę stanowiły 28,57\% - 30 osób, 15 dzieci tj. 14,29\% gorączkowało krócej niż 8 godzin, a zbliżoną liczbę stanowiły dzieci gorączkujące od 8-24 godzin (15 osób co stanowi 13,33\%).

Wśród badanej grupy najwięcej gorączkujących $(95,24 \%)$ stanowiły dzieci, u których ciepłota mieściła się w granicach 38 - 39 stopni C, tylko 3,81\% - 4 dzieci miało temperaturę ciała powyżej 39 stopni C, a jedno dziecko nie osiągnęło ciepłoty 38 stopni C w momencie wizyty u lekarza.

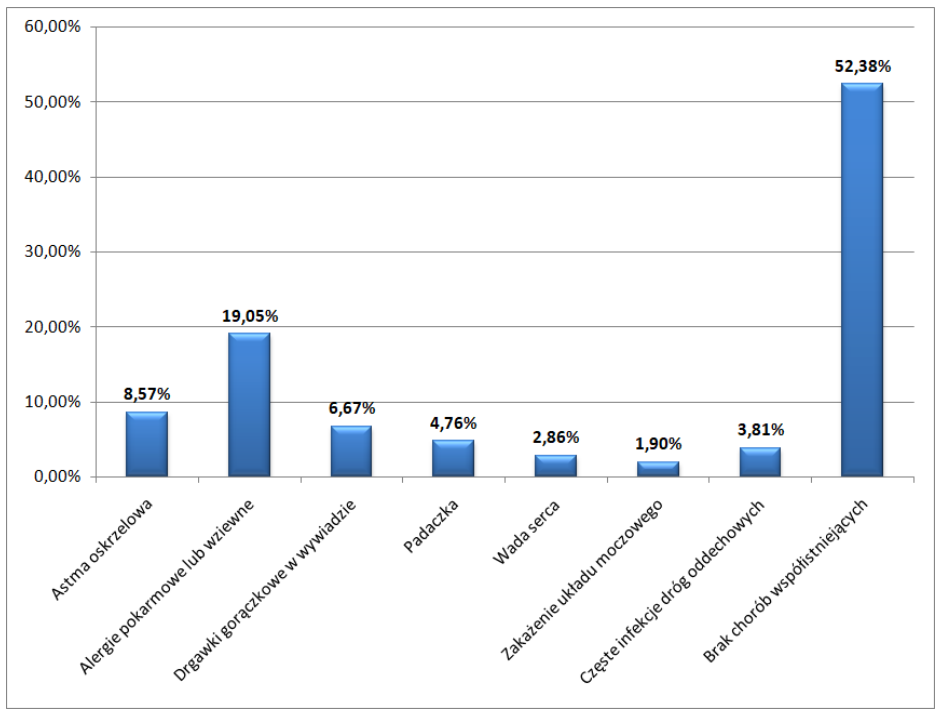

Rycina 1. Charakterystyka badanej grupy ze względu na choroby współistniejące badanych.

Większość dzieci nie miała chorób współistniejących (55,38\% 55 osób), kolejno pojawiały się u dzieci inne schorzenia tj. alergie 20 dzieci, astma oskrzelowa - 9 dzieci, drgawki gorączkowe 
w przeszłości - 7 dzieci, padaczka - 5 dzieci, częste infekcje górnych dróg oddechowych - 4 dzieci, wada serca - 3 dzieci i zakażenia układu moczowego w przeszłości - 2 dzieci.

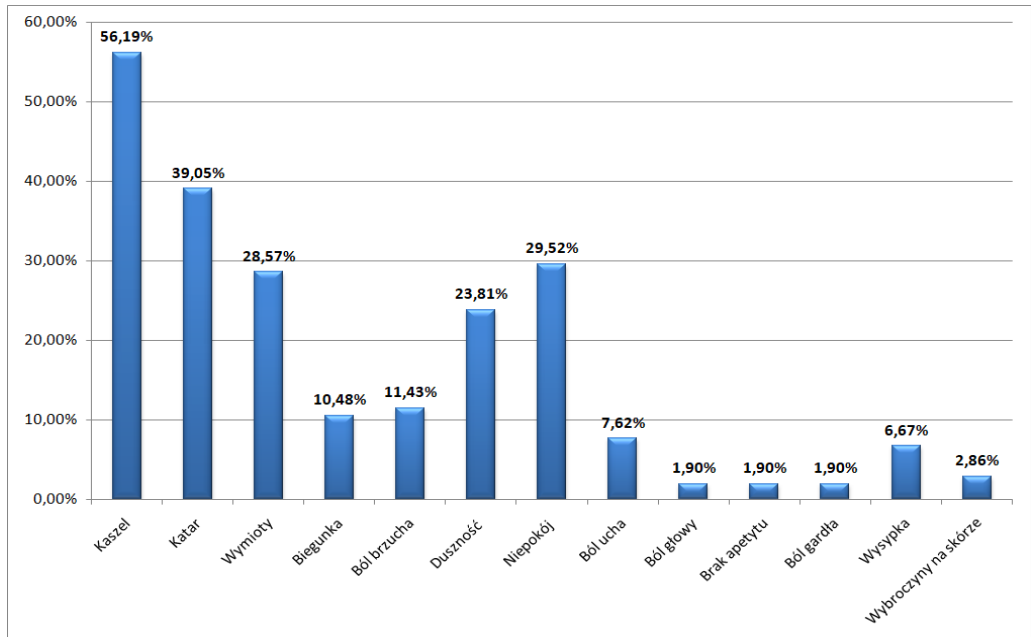

Rycina 2. Charakterystyka badanej grupy ze względu na objawy współistniejące.

Najczęściej u badanych dzieci gorączce towarzyszył kaszel (56,19\% tj. 59 dzieci), kolejnymi objawami były: katar, niepokój, wymioty, duszność, ból brzucha i biegunka. Mniej niż 10\% wszystkich dzieci stanowiły dzieci, u których rodzice zgłaszali ból ucha, wysypkę, wybroczyny na skórze, ból głowy, ból gardła i brak apetytu.

U większości dzieci stwierdzono czynnik bakteryjny infekcji (58,10\% - 51 dzieci), a czynnik wirusowy był prawdopodobną przyczyną choroby u 44 dzieci, co stanowi $41,90 \%$ badanej grupy.

Najczęściej u dzieci zastosowano leki przeciwgorączkowe (74,29\% - 78 dzieci), równocześnie u 63 dzieci (60\%) leczeniem z wyboru była antybiotykoterapia i płynoterapia, 33 dzieci $(31,43 \%)$ miało wykonane inhalacje. 


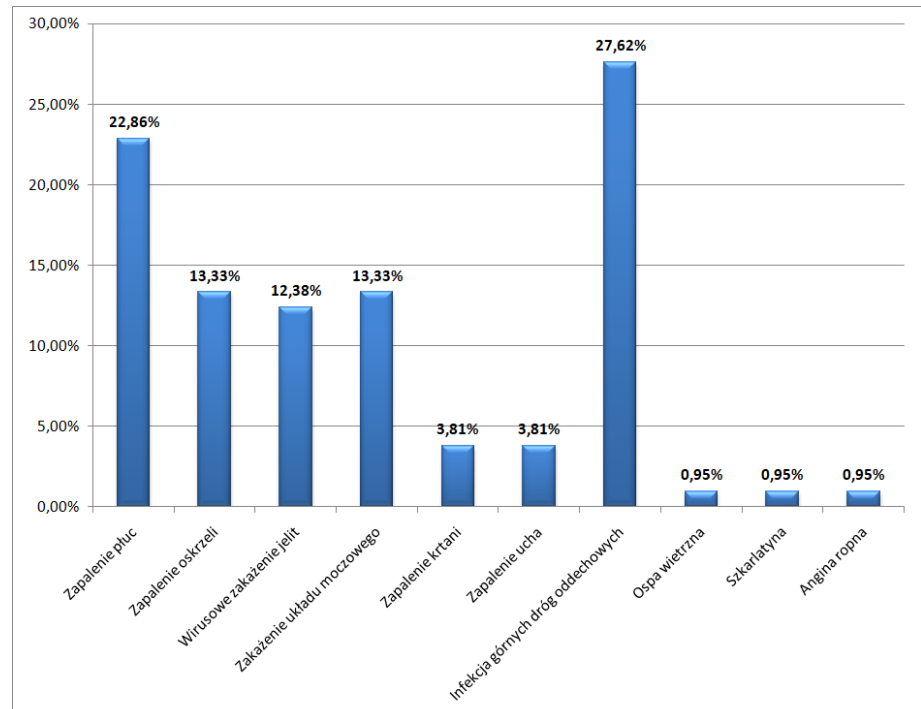

Rycina 3. Charakterystyka badanej grupy ze względu na ostateczne rozpoznanie lekarskie.

Najczęściej u badanych dzieci rozpoznano infekcję górnych dróg oddechowych $(27,62 \% \quad-29$ dzieci), odpowiednio kolejno zdiagnozowano: zapalenie płuc $(22,86 \%)$, zapalenie oskrzeli (13,33\%), zakażenie układu moczowego (13,33\%), wirusowe zakażenie jelit $(12,38 \%)$, zapalenie ucha $(3,81 \%)$ i zapalenie krtani $(3,81 \%)$. Pojedynczo u trojga dzieci rozpoznano ospę wietrzną, szkarlatynę i anginę ropną.

\section{Informacje zaczerpnięte od rodziców}

Największa grupa rodziców uważa za gorączkę wartości temperatury w przedziale 38,1-39 stopni C (6,81\% - 67 osób). Wartości w przedziale 37,1-38 stopni C za gorączkę uważa 36 osób tj. 34,29\%. Jedna osoba za gorączkę uważa ciepłotę do 37 stopni C, a również jedna temperaturę ponad 39 stopni C. 
Za wysoką gorączkę 59,05\% rodziców (62 osoby) uważa temperaturę w przedziale 39,1 - 40 stopni C a 27,62\% (29 osób) temperaturę w granicach 38 - 39 stopni C. Aż 7 osób uważa, że wysoka gorączka ma wartość poniżej 38 stopni C i również 7 osób, że jest to wartość ponad 40 stopni.

Największa ilość rodziców deklaruje pomiar ciepłoty w okolicy czołowej (50,48\% - 53 osoby), równocześnie 48,57\% rodziców (51 osób) mierzy ją pod pachą. Jedna osoba stwierdziła, że mierzy ciepłotę $\mathrm{w}$ pachwinie. Nikt z rodziców nie dokonuje pomiaru w jamie ustnej

i odbycie.

Najczęściej rodzice rozpoczynają podawanie leków obniżających gorączkę, gdy osiąga ona wartości 38,1 - 39 stopni C (56,19\% tj. 59 osób), a w przedziale 37,6 - 38 stopni C rozpoczyna leczenie przeciwgorączkowe $36,19 \%$ rodziców (38 osób). Aż sześcioro opiekunów $(5,71 \%)$ podaje leki dziecku, by obniżyć ciepłotę już przy temperaturze ciała 37 - 37,5 stopni C. Dwóch rodziców podaje, że wartością początkową dla obniżenia gorączki jest temperatura ciała powyżej 40 stopni C.

Największa liczba rodziców uważa, że zagrożeniem dla ich dziecka jest gorączka powyżej 40 stopni C (60\% - 63 osoby). Dla $28,57 \%$ ankietowanych zagrożeniem jest ciepłota ponad 39 stopni (30 osób), a ciepłotę już powyżej 38 stopni C za zagrożenie podaje 8 osób tj. 7,62\%. Najmniejsza ilość rodziców podała wartość ponad 41 stopni C $(3,81 \%)$ za niebezpieczne.

Najwięcej rodziców podaje, że kontroluje ciepłotę w czasie choroby co godzinę (39,05\% - 41 osób). Rzadziej niż co godzinę robi to $21,90 \%$ badanych (23 osoby). Pozostali rodzice mierzą ciepłotę co 30 min. (18 osób - 17,14\%), a co 45 min. 14 osób co stanowi 13,33\%. Najmniejszą wartość stanowią opiekunowie kontrolujący ciepłotę najczęściej co 15 min. ( 9 osób -8,57\%). 
Rodzice najczęściej deklarują posiadanie termometrów elektronicznych (56,19\% - 59 osób), a termometry rtęciowe są w posiadaniu 33,33\% badanych (35 osób). 10 ankietowanych podaje, że posiada inny typ termometru $(9,52 \%)$, a jedna osoba stwierdziła, że nie posiada żadnego termometru.

Aż 97,14\% wszystkich rodziców preferuję drogę doustną (102 osoby), a tylko trzy osoby podały, że droga doodbytnicza jest dla nich odpowiednia dla podania choremu dziecku leku przeciwgorączkowego (2,86\%).

- stosuję się

ściśle do

zaleceń

pediatry; 48,57

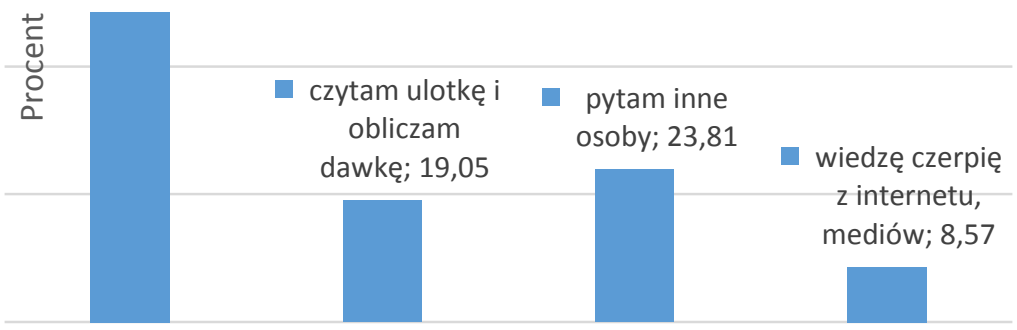

Rycina 4. Rozkład posiadanej wiedzy na temat obliczania dawki leku przeciwgorączkowego.

Rodzice w ilości 51 osób (48,57\%) podają, że ich dziecko otrzymuje lek przeciwgorączkowy $\mathrm{w}$ dawce zleconej przez lekarza. Pozostała grupa ankietowanych czerpie wiedzę z innych źródeł, tj. 23,81\% -25 osób - pyta inne osoby, 19,05\% - 20 osób czyta ulotkę i weryfikuje obliczenia, a 9 osób (8,57\%) czerpie informacje z mediów i Internetu. 
Najczęściej rodzice uznają, że trzeba znać wagę i wiek dziecka, żeby obliczyć dawkę podanego leku (86 osób - 81,90\%). Za konieczne parametry 12 rodziców uznało wagę i wzrost $(11,43 \%)$, cztery osoby wzrost i płeć $(3,81 \%)$, a według trojga opiekunów $(2,86 \%)$ do obliczenia dawki niezbędne jest podanie płci i wagi dziecka.

Rodzice w 54,29\% twierdzą, że podają lek doodbytniczo, gdy dziecko wymiotuje (57 osób), a 35 osób stwierdziło, że akceptują tę formę, gdy dziecko nie chce wypić leku (33,33\%). Z powodu niepokoju dziecka 5 osób wybrało taką drogę podania syropu $(4,76 \%)$, a osiem osób oceniło, że podaje czopek, bo nie ma leku w innej niż ta postaci $(7,62 \%)$.

Największa liczba rodziców odmierza konieczną dawkę leku za pomocą strzykawki $(44,76 \%)$ i specjalnej miarki do leku $(40,95 \%)$. Rodzice stosują też to tego celu łyżeczki (13,33\% - 14 osób), a jedna osoba używała miarki z innego leku $(0,95 \%)$.

Według większości rodziców (103 osoby tj. 98,10\%) maksymalna dawka leku przeciwgorączkowego jest skuteczna, a dwie osoby $(1,90 \%)$ uważają, że jest ona niebezpieczna dla dziecka.

Twierdząco na temat postępowania przeciwgorączkowego odpowiedziało 39,05\% badanych tj. 41 osób, a 15 osób stwierdziło, że nie ma posiada wystarczającej wiedzy na ten temat $(14,29 \%)$. Aż 46,67\% tj. 49 ankietowanych nie potrafi określić stopnia swojej wiedzy.

Zdecydowana większość rodziców zna podstawowe leki stosowane w gorączce, 99,05\% - 104 osoby podało, że zna paracetamol, a 97,14\% - 102 osoby zna ibuprofen. 43 osoby $(40,95 \%)$ podały pyralginę, a 17 osób (16,19\%) aspirynę, jako znane im leki. Trzy osoby $(2,86 \%)$ podały, że znają inne leki, które mają takie działanie.

Za niebezpieczne dla dziecka z gorączką w 96,19\% rodzice uznali drgawki gorączkowe (101 osób). Inne niepokojące skutki 
gorączki to utrata przytomności (36 osób - 34,29\%) i odwodnienie (31 osób - 29,52\%). Nikt z ankietowanych nie podał, że nie zna żadnego niebezpieczeństwa.

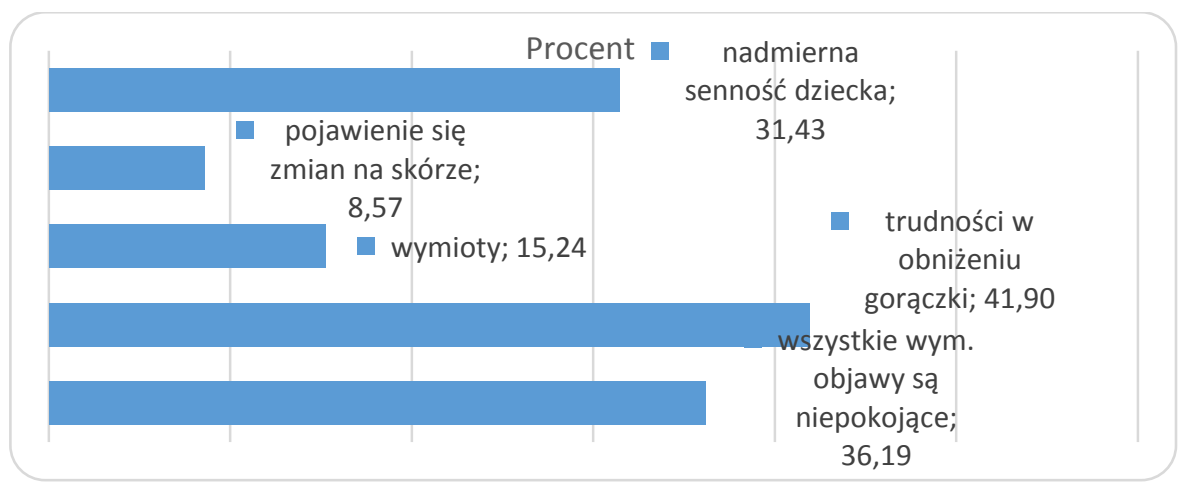

Rycina 5. Rozkład innych niepokojących objawów w czasie gorączki według rodziców.

Rodzice za najbardziej niepokojące uznają trudności w obniżeniu gorączki $(41,90 \%$ tj. 44 osoby). Również nadmierna senność dziecka $(31,43 \%)$ i wymioty $(15,24 \%)$ są dla nich powodem do niepokoju. Dziewięć osób podało, że niepokojące zmiany na skórze są niebezpieczne $(8,57 \%)$. Wszystkie $\mathrm{z}$ podanych objawów są niepokojące dla 38 osób $(36,19 \%)$. 


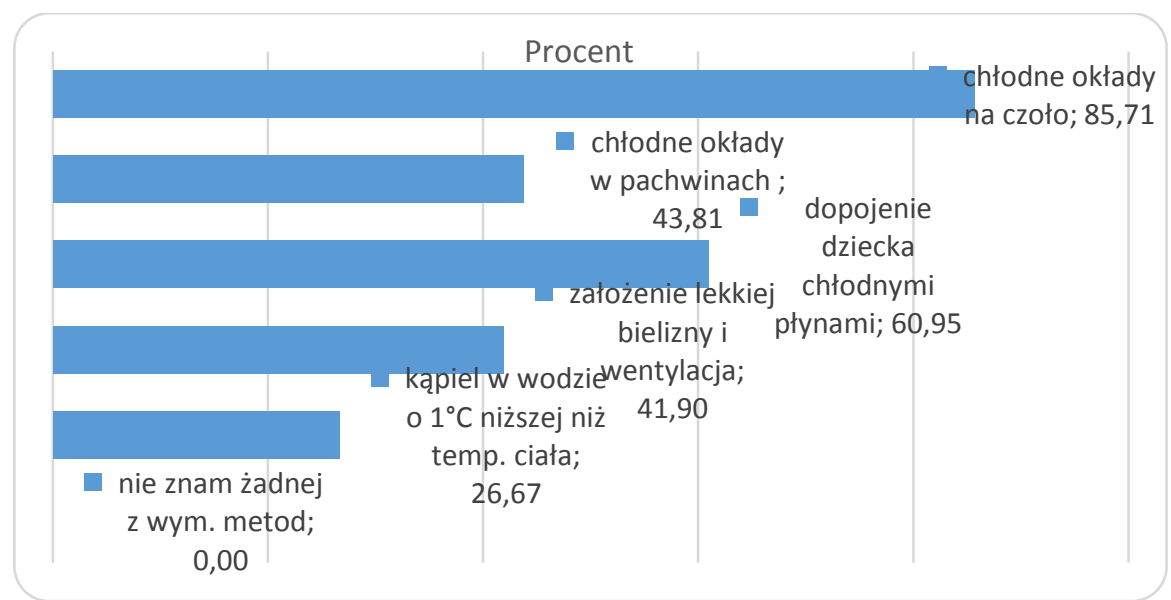

Rycina 6. Rozkład posiadanej wiedzy na temat innych metod obniżenia gorączki.

Rodzice najczęściej wśród niefarmakologicznych metod znają stosowanie chłodnych okładów na czoło $(85,71 \%)$ i dopajanie dziecka chłodnymi płynami $(60,95 \%)$. Inne metody to chłodne okłady w pachwinach $(43,81 \%)$ i założenie dziecku lekkiej bielizny $(41,90 \%)$. 28 osób (26,67\%) podało, że wie, iż jedną z metod jest kąpiel dziecka w wodzie niższej o 1 stopień $\mathrm{C}$ niższej niż temperatura ciała. Nikt $\mathrm{z}$ rodziców nie podał, że nie zna żadnej z metod.

Według rodziców pielęgniarka w największym stopniu naucza ich, jak postępować w razie gorączki (62 osoby - 59,05\%). Również lekarz jest źródłem informacji co podało 39 osób $(37,14 \%)$. Nikt nie podał położnej jako źródła informacji. Dla czterech osób inne osoby edukowały je w tym zakresie $(3,81 \%)$, nie podały one, kto konkretnie był tą osobą.

Rodzice w większości (60 osób tj. 57,14\%) ocenili, że wiedza pielęgniarek w zakresie edukacji postępowania przeciwgorączkowego była najbardziej wyczerpująca. Na lekarza wskazało 39 osób $(37,14 \%)$. Cztery ankietowane osoby $(3,81 \%)$ oceniły, że najbardziej 
wyczerpujące informacje uzyskują z innych źródeł, nie podając jakich. Dwie osoby $(1,90 \%)$ stwierdziły, że od nikogo $z$ personelu nie uzyskały wyczerpujących informacji.

Rodzice dzieci w zdecydowanej większości ocenili pozytywnie poziom działań edukacyjnych personelu medycznego. 41,90\% badanych wskazało na poziom dostateczny, 40,95\% na dobry poziom edukacji, a 2,86\% na bardzo dobry poziom. Łącznie dało to ponad $85,00 \%$ pozytywnych ocen. 15 ankietowanych rodziców $(2,86 \%)$ wskazało na niezadowalający poziom edukacji i oceniło go niedostatecznie.

Średnia $\mathrm{M}=3,32$, odchylenie standardowe $\mathrm{SD}=0,75$

\section{Stan wiedzy i sposoby postępowania rodziców}

W użytym kwestionariuszu znalazło się 17 pytań o zróżnicowanym poziomie trudności. W przypadku pytań łatwych prawidłową odpowiedź punktowano wartością 0,5 pkt, w przypadku najtrudniejszych, mających postać wielokrotnego wyboru, maksymalna przydzielana liczba punktów wyniosła 2,5 pkt. Łączna liczba punktów do zdobycia wyniosła 17 pkt. Badana grupa uzyskała średnią punktową $\mathrm{M}=11,14$ przy odchyleniu standardowym $\mathrm{SD}=2,81$. Najniższa zanotowana sumaryczna wartość punktowa wyniosła $5 \mathrm{pkt}$, najwyższa to komplet 17 punktów. Całościowo należałoby ocenić grupę nieco lepiej niż przeciętnie, odwołując się do szkolnego systemu ocen można byłoby wystawić ocenę „3+”.

Analiza przeprowadzona testem Shapiro-Wilka nie wykazała istotnego odbiegania zmiennej od rozkładu normalnego $(p=0,243)$. Podobne rezultaty dały testy normalności przeprowadzane we wszystkich stosowanych konfiguracjach względem zmiennej niezależnej. Ponadto analiza jednorodności wariancji (test Levene’a) również wskazywała na spełnienie założeń dotyczących wykorzystania testów parametrycznych. 
Tabela 1. Uzyskane oceny w odniesieniu do badanej próby.

\begin{tabular}{|c|c|c|}
\hline Zakres punktowy & Ilość osób & Procent \\
\hline 0 -5 bardzo niski poziom & 1 & 0,95 \\
\hline 6 - 8 niski poziom & 22 & 20,95 \\
\hline 9-11 przeciętny poziom & 39 & 37,14 \\
\hline 12 - 14 wysoki poziom & 30 & 38,57 \\
\hline $\begin{array}{l}15-17 \text { bardzo wysoki } \\
\text { poziom }\end{array}$ & 13 & 13,28 \\
\hline Razem & 105 & 100 \\
\hline
\end{tabular}

W kolejnym kroku dokonano analizy wpływu zmiennych niezależnych takich jak: płeć, wiek, wykształcenie, miejsce zamieszkania, sytuacja materialna oraz liczba dzieci na zmienną zależną, czyli utworzoną sumaryczną skalę punktową.

Płeć a wiedza i postępowanie rodziców

W celu zweryfikowania hipotezy o istotnym wpływie płci na sumaryczną skalę punktową użyto testu $t$ (Studenta) dla zmiennych niezależnych. Metoda ta służy do oceny istotności różnic pomiędzy średnimi w dwóch porównywanych grupach.

Przeprowadzona analiza nie wykazała istnienia różnic pomiędzy porównywanymi średnimi, wynik testu okazał się nieistotny statystycznie $(\mathrm{p}=0,306)$. Oznacza to, iż nie dowiedziono by płeć istotnie statystycznie wpływała na wiedzę i postępowanie przeciwgorączkowe rodziców. Warto jednak zaznaczyć, iż w badaniu wystąpiła znaczna dominacja kobiet, dlatego do wniosków należy podchodzić

z ostrożnością.

\section{Wiek a wiedza i postępowanie rodziców}

Analizę wpływu podziału na trzy kategorie wiekowe na poziom wiedzy i postępowanie rodziców przeprowadzono przy wykorzystaniu jednoczynnikowej analizy wariancji. Metoda ta służy do porównywania średnich $w$ więcej niż dwóch grupach. Analizę 
porównań wielokrotnych wykonano używając testu RiRTukeya w wersji dla nierównych liczebności.

Wynik zastosowanego testu analizy wariancji jest istotny statystycznie $(\mathrm{p}=0,033)$ co oznacza, iż są podstawy do przyjęcia hipotezy o tym, że podział na trzy kategorie wiekowe jest czynnikiem różnicującym poziom mierzonej zmiennej zależnej. Wyliczone wartości średnich arytmetycznych wskazują, iż najlepszą wiedzą i postawą charakteryzują się rodzice w wieku powyżej 40 lat (średnia $\mathrm{M}=12,33$ ) a najniższe wyniki uzyskują rodzice najmłodsi, $\mathrm{z}$ grupy do 30 lat (średnia $M=10,14$ ). Przeprowadzona analiza post-hoc wykazała, iż istotne różnice zachodzą jedynie pomiędzy najmłodszą i najstarszą grupą respondentów ( $\mathrm{p}=0,033)$.

\section{Wykształcenie a wiedza i postępowanie rodziców}

Przeprowadzone obliczenia dają podstawy do odrzucenia hipotezy zerowej i przyjęcia alternatywnej. Oznacza to, iż dowiedziono istnienia istotnego statystycznie $(\mathrm{p}=0,003)$ wpływu wykształcenia rodziców na poziom ich wiedzy i jakość postępowania przeciwgorączkowego. Najniższymi średnimi wartościami zmiennej zależnej cechowali się badani $\mathrm{z}$ wykształceniem podstawowym lub zawodowym $(M=9,77)$, a najwyższymi wynikami charakteryzowali się respondenci $\mathrm{z}$ wykształceniem wyższym $(\mathrm{M}=12,40)$. Analiza porównań wielokrotnych wykazała, iż istotna różnica występuje pomiędzy osobami najsłabiej i najlepiej wykształconymi $(\mathrm{p}=0,003)$.

\section{Sytuacja materialna a wiedza i postępowanie rodziców}

Przeprowadzone obliczenia nie dają podstaw do odrzucenia hipotezy zerowej. Nie wykazano istotnego statystycznie wpływu sytuacji materialnej na poziom mierzonej zmiennej zależnej $(\mathrm{p}=0,340)$.

\section{Miejsce zamieszkania a wiedza i postępowanie rodziców}

Nie wykazano istotnego statystycznie wpływu miejsca zamieszkania na poziom zmiennej zależnej. Warto jednak zaznaczyć, 
iż w toku obliczeń otrzymano wynik bardzo bliski przyjętej granicy istotności statystycznej, co oznacza rezultat na poziomie tendencji do istotności $(p=0,083)$. Porównując średnie można zauważyć, iż mieszkańcy miast uzyskują nieco lepsze rezultaty w przeprowadzonym teście.

\section{Liczba dzieci $w$ rodzinie a wiedza i postępowanie rodziców}

Uzyskano wynik istotny statystycznie $(p=0,039)$, co oznacza, iż liczba dzieci w rodzinie jest czynnikiem wpływającym na poziom wiedzy i postępowanie przeciwgorączkowe rodziców. Porównując uzyskane średnie punktowe można zauważyć, iż rodzice trójki lub więcej dzieci cechują się wyższym poziomem zmiennej zależnej niż rodzice jedynaków lub dwójki dzieci (obie te grupy mają bardzo zbliżone wyniki). Zaobserwowane różnice okazały się jednak zbyt małe, by szczegółowa analiza post-hoc dała rezultat istotny statystycznie.

\section{Dyskusja}

W wyniku przeprowadzonej oceny poziomu wiedzy opiekunów, według sumarycznej skali punktowej własnej konstrukcji, dowiedziono, że jej poziom można porównać do oceny dostatecznej plus według skali ocen szkolnych. Jest to więc wiedza niewystarczająca i należy dążyć do jej pogłębiania. Ankietowani znają częściowo metody obniżania gorączki. Rodzice dzieci znają natomiast $\mathrm{w}$ stopniu odpowiednim zagrożenia wynikające $\mathrm{z}$ pojawienia się gorączki

u dziecka. Są świadomi, że dużym zagrożeniem dla dziecka do 5 roku życia są drgawki gorączkowe, a u dzieci, u których występowały już epizody drgawek gorączkowych wcześniej, są niebezpieczne szczególnie i zagrażają ich życiu. Aż 96,19\% rodziców potwierdziło swoją wiedzę w tym temacie. 
W literatura potwierdza, że rodzice nie posiadają dostatecznej wiedzy na tematy dotyczące np. stosowania niefarmakologicznych metod obniżenia gorączki, jak i nie rozumieją mechanizmu działania tych metod. Nie potrafią prawidłowo rozpoznać gorączki, nieprawidłowo interpretują zależność wysokości ciepłoty ciała od miejsca jej pomiaru [1,2]. Według Jackowskiej i wsp. szeroko rozpowszechnione jest zjawisko tzw. „fobii gorączkowej”, a wiedza rodziców na temat gorączki jest niezadowalająca [3]. CzerwionkaSzaflarska i wsp. określa stan wiedzy rodziców o gorączce jako niewystarczający. Dotyczy to ich znajomości przebiegu gorączki, interpretacji pomiaru, doboru leków, a głównie ich dawkowania [4]. Łoś-Rycharska i wsp. oceniają niedostatecznie wiedzę rodziców w zakresie podawania nieprawidłowych dawek leków przeciwgorączkowych $\mathrm{w}$ niewłaściwych odstępach czasu [5]. W innych badaniach zaobserwowano brak wiedzy rodziców na temat niefarmakologicznych metod obniżania gorączki, co może być niebezpieczne i narażać dziecko na pojawienie się niepożądanych objawów [6].

Analiza wieku rodziców dowodzi, że rodzice mający ponad 40 lat wykazują się najwyższą wiedzą, a najmłodsi poniżej 30 roku życia uzyskują najniższe wyniki. Płeć rodzica nie miała statystycznie istotnego znaczenia dla badanego problemu, ale większość respondentów to matki, gdyż to one najczęściej były obecne przy dzieciach $w$ czasie prowadzenia badań( $p>0,05)$. Istotne znaczenie miało natomiast wykształcenie rodziców. Opiekunowie ze średnim i wyższym wykształceniem posiadają większą wiedzę o gorączce i radzeniu sobie $\mathrm{z}$ nią niż rodzice $\mathrm{z}$ wykształceniem podstawowym lub zawodowym $(\mathrm{p}<0,05)$. Sytuacja materialna rodziny dziecka według przeprowadzonych badań nie wpływa znacząco na wiedzę o gorączce. Nie wykazano istotnego statystycznie znaczenia, aby miejsce zamieszkania rodziców, będące aglomeracją wiejską lub miejską, było 
czynnikiem modyfikującym( $\mathrm{p}>0,05)$. W rodzinach wielodzietnych natomiast wiedza rodziców o postępowaniu przeciwgorączkowym jest większa niż w rodzinach z mniejszą ilością potomstwa.

Według Łoś-Rycharskiej i wsp. prawidłowa ocena gorączki i postępowanie $\mathrm{w}$ przypadku jej wystąpienia u małych dzieci, jest znacznie większa u rodziców posiadających liczniejsze potomstwo i wzrasta z ich ilością. Również doświadczenie własne rodziców, ich wiek, płeć i wykształcenie mają istotne znaczenie. Matki lepiej radzą sobie z obniżeniem gorączki i lepiej interpretują zależność temperatury od miejsca jej pomiaru. $\mathrm{W}$ badaniach tych jednak nie wykazano istotnego wpływu wykształcenia rodziców na ocenę gorączki u dziecka [1]. Według Czerwionki - Szaflarskiej rodzice starsi w sytuacji gorączki u swojego dziecka mają mnie zachowań lękowych, lepszą wiedzę i reagują spokojem w sytuacji stresowej [4]. Rodzice jedynaków i mający niższy poziom wykształcenia szybciej też szukają pomocy lekarza $\mathrm{w}$ sytuacji pojawienia się gorączki, co potwierdza w swoich badaniach Sterkowicz i wsp. [7,1]. Uzyskane wyniki badań własnych oraz wyniki innych autorów potwierdzają modyfikujący wpływ wyżej wymienionych czynników demograficznych w postępowaniu przeciwgorączkowym u dzieci do 5 roku życia.

Aż 51,43\% opiekunów wskazywało, że obliczając dawkę leku przeciwgorączkowego sugeruje się informacjami pochodzącymi od koleżanek, innych matek poznanych na forach internetowych czy dziadków, sami czytają ulotki leku i próbują obliczyć dawkę leku, często zaniżając ją do wartości minimalnych, aby „nie zaszkodzić swojemu dziecku". Personel medyczny jest źródłem wiedzy dla 48,57\% rodziców, głównie dopiero w czasie wizyty w gabinecie lekarskim. Własne doświadczenie poparte wieloletnią pracą badaczy w oddziale pediatrycznym wskazuje, że wiedza rodziców o gorączce i metodach postępowania $w$ przypadku jej wystąpienia jest zdobywana wybiórczo, zbyt płytko i niedbale. Nagminnie spotyka się 
sytuacje,

w których rodzice nie próbują zrozumieć przekazywanych im informacji i spokojnie ich wysłuchać, reagują niekiedy niegrzecznie, a nawet agresywnie. Niestety nie wszystkie sytuacje można wytłumaczyć obawą o zdrowie i życie dziecka i stresem z tym związanym. Wybiórcze i niepełne czerpanie wiedzy przez rodziców o radzeniu sobie $\mathrm{z}$ gorączką $\mathrm{i}$ w chorobie jest też dość często wynikiem zmniejszonych możliwości jej przyswojenia. Niski poziom wykształcenia niektórych rodziców często towarzyszy ich niższej sprawności intelektualnej, co sprawia, że matka czy ojciec nie są w stanie w pełni przyswoić i zrozumieć przekazanych informacji i zastosować w opiece nad chorym dzieckiem.

Literatura również podaje, że rodzice jednak najczęściej informacje o wyborze leku przeciwgorączkowego i sposobach jego dawkowania uzyskują w czasie wizyty u pediatry. Rzadziej źródłem wiedzy jest farmaceuta, informacje $\mathrm{z}$ Internetu czy własne doświadczenie $[8,2]$.

Według Łoś-Rycharskiej i wsp. w środowisku wiejskim i w rodzinach wielodzietnych, gdzie dostęp do pediatry jest często ograniczony i utrudniony źródłem wiedzy o gorączce jest najczęściej własne doświadczenie, a postępowanie tych rodziców racjonalne i przemyślane [2].

Aż 59,05\% rodziców potwierdziło, że to właśnie pielęgniarka najczęściej edukowała ich w tym zakresie, a 37,14\% wskazało na lekarza. Większość respondentów $(57,14 \%)$ oceniła poziom tej edukacji jako wyczerpujący. Oceniając jakość przekazywanych informacji na ocenę dobrą wskazało 40,95\% opiekunów, a dostateczną $41,90 \%$.

Według opracowań dostępnych $\mathrm{w}$ literaturze wskazuje się na konieczność edukowania rodziców przez personel medyczny. Łoś Rycharska i wsp. uważa, że to lekarze pierwszego kontaktu powinni 
położyć większy nacisk na informowanie rodziców o postępowaniu przeciwgorączkowym [5]. Dodatkowo wskazuje na konieczność prowadzenia edukacji rodziców na temat różnic w pojęciach gorączka a hipertermia, ponieważ wpływa to na różnice $\mathrm{w}$ postępowaniu w tych sytuacjach [9]. Jackowska i wsp. uważają za niezbędne zastosowanie programów edukacyjnych dla rodziców i opiekunów dzieci w zakresie wiedzy o gorączce [3]. Smoleń i Ksykiewicz - Dorota dowodzą, że rodzice oceniają profesjonalizm pielęgniarek przede wszystkim na podstawie ich empatii, życzliwości oraz sprawności w wykonywaniu czynności pielęgniarskich w stosunku do ich dziecka. Oznaczać to może, że pielęgniarki zbyt małą wagę przykładają do swojej funkcji edukacyjnej, jaką niewątpliwie powinny wypełniać [10].

\section{Wnioski}

1. Na wiedzę rodziców i ich postępowanie $\mathrm{w}$ przypadku wystąpienia gorączki u dziecka do 5 roku życia wpływają określone czynniki demograficzne i społeczno - ekonomiczne. Rodzice wykształceni, starsi i posiadający liczniejsze potomstwo lepiej radzą sobie z gorączką, a ich wiedza jest wystarczająca. Płeć rodzica, jego sytuacja ekonomiczna i miejsce zamieszkania w mniejszym stopniu jest wyznacznikiem ich wiedzy.

2. Wiedza rodziców w zakresie gorączki i metod jej obniżenia jest niewystarczająca. Odpowiedzialność za zdrowie dziecka wymaga od nich, aby zdobywali ją i odpowiednio wykorzystywali. Rodzice znają niebezpieczeństwa związane $\mathrm{z}$ wysoką gorączką, mają świadomość zagrożeń $\mathrm{z}$ powodu wystąpienia drgawek gorączkowych.

3. Sposoby zdobywania przez opiekunów wiedzy o postępowaniu przeciwgorączkowym są niepełne i wybiórcze. Głównym źródłem 
wiedzy powinien być fachowy personel medyczny. Poziom przekazywanej wiedzy musi być dostosowany do możliwości intelektualnych rodzica.

4. Rola pielęgniarki w edukacji rodziców o gorączce i postępowaniu w przypadku jej pojawienia się jest znacząca.

\section{Zalecenia dla praktyki pielęgniarskiej}

Należy edukować rodziców dzieci $\mathrm{z}$ wysoką temperaturą, zagrożonych wystąpieniem drgawek gorączkowych o konieczności utrzymywania stałej wartości temperatury, zabezpieczyć dziecko przed urazem podczas incydentu drgawkowego i przed nawrotem drgawek. Podawanie leków obniżających temperaturę i stosowanie działań pielęgnacyjnych jest niezwykle istotne, a podawanie leków przeciwdrgawkowych jest konieczne wśród dzieci spełniających pewne kryteria. Profilaktyka nie zmniejsza ryzyka kolejnych napadów drgawek gorączkowych

\section{Bibliografia/Bibliography:}

1. Łoś - Rycharska E., Sterkowicz A. i wsp. Wpływ doświadczeń własnych, czynników demograficznych oraz wykształcenia rodziców na prawidłowość interpretacji temperatury ciała u dziecka. Pediatria Polska, 2015;9:32-38.

2. Łoś - Rycharska E., Sterkowicz A. i wsp. Źródła wiedzy o postępowaniu przeciwgorączkowym u rodziców. Pediatria Polska. 2015;90:113-118.

3. Jackowska T., Sapała - Smoczyńska A. i wsp. Wiedza rodziców o gorączce i o zasadach postępowania w przypadku jej wystąpienia u dzieci do 12 roku życia. Postępy Nauk Medycznych. 2014;9:633-341.

4. Czerwionka - Szaflarska M., Łoś - Rycharska E. Gorączka u dzieci: codzienna praktyka a zalecenia, $\mathrm{z}$ uwzględnieniem postępowania 
w sytuacjach nagłych i szczególnych. Standardy Medyczne/Pediatria. 2015, t.12.

5. Łoś - Rycharska E., Sterkowicz A. i wsp. Farmakoterapia gorączki u dzieci, postępowanie rodziców przed uzyskaniem porady lekarskiej. Pediatria Polska. 2015;90:39-47.

6. Łoś - Rycharska E., Sterkowicz A. i wsp. Niefarmakologiczne metody obniżenia ciepłoty ciała u dzieci gorączkujących - analiza postępowania rodziców na podstawie badania ankietowego. Pediatria Polska. 2016;91:122-127.

7. Łoś - Rycharska E., Sterkowicz A. i wsp. Sposoby oceny przez rodziców ciepłoty ciała dzieci. Pediatria Polska. 2014;89:415-422.

8. Łoś - Rycharska E., Sterkowicz A. i wsp. Gorączka u dzieci - decyzje rodziców dotyczące farmakoterapii. Pediatria Polska. 2015;90:402-407.

9. Łoś - Rycharska E., Sterkowicz A. i wsp. Przekonania rodziców dotyczące stosowania antybiotyków w przebiegu gorączki u dziecka oraz pozainfekcyjnych przyczyn gorączki. Pediatria Polska. 2015;90:302-307.

10. Smoleń E., Ksykiewicz - Dorota A. Profesjonalizm pielęgniarek jako element oceny satysfakcji rodziców/opiekunów z opieki pielęgniarskiej. Medycyna Pracy. 2015; 66:549-556. 